Research Article

\title{
A Comparative Study on Prevalence of Anaemia among Rural \& Urban Pregnant Women in a Selected Hospital of Kashmir with a View to Prepare Information Module on Prevention of Anaemia
}

\author{
Roquia Bano
}

Tutor, Mader E Maherban Institute of Nursing Sciences \& Research, Sher-I-Kashmir Institute of Medical Sciences, Srinagar, Jammu and Kashmir, India.

DOI: https://doi.org/10.24321/2455.9318.202027

\section{I $\quad \mathbf{N} \quad \mathbf{F} \quad \mathbf{O}$}

E-mail Id:

shahroquia1962@gmail.com

Orcid Id:

https://orcid.org/0000-0002-8085-6188

How to cite this article:

Bano R. A Comparative Study on Prevalence of Anaemia among Rural \& Urban Pregnant Women in a Selected Hospital of Kashmir with a View to Prepare Information Module on Prevention of Anaemia. Int J Nurs Midwif Res 2020; 7(4): 1-7.

Date of Submission: 2020-09-25

Date of Acceptance: 2020-10-18

\section{$\begin{array}{lllllllllllllll}\mathbf{A} & \mathbf{B} & \mathbf{S} & \mathbf{T} & \mathbf{R} & \mathbf{A} & \mathbf{C} & \mathbf{T}\end{array}$}

Anaemia in pregnancy exists worldwide. In Jammu and Kashmir 58.7\% of women are anemic compared to national average of $51.8 \% .17 .6 \%$ suffer from moderate anaemia compared to national average of $14.8 \%$. The present study was aimed to compare the prevalence of anaemia among rural (50) and urban (50) pregnant subjects using descriptive comparative survey design. Purposive sampling technique was used for data collection. The study found mild anaemia (98\%) among rural and $(100 \%)$ among urban subjects. Moderate anaemia was found (2\%) only among rural subjects. Both urban and rural pregnant subjects had significant association of nutritional status with socioeconomic status.

Keywords: Anaemia, Prevalence, Pregnant, Rural, Urban, Socioeconomic Status

\section{Introduction}

Anaemia is defined as the condition in which there is decreased level of hemoglobin than the normal or there is decreased number of RBC's than the normal value. WHO has defined anaemia during pregnancy as hemoglobin concentration of less than $11 \mathrm{gm} \%$ and a hematocrit of less than $33 \%$. In a study conducted by Bala ${ }^{1}$ and according to WHO in developing countries the prevalence of anaemia among pregnant women averages $56 \%$ that is ranging between $35-100 \%$ among different regions of the world. India reported the prevalence to be between 33\% to $100 \%$. About $60 \%$ of all pregnant women in developing countries all over the world have anaemia, out of which $40 \%$ of maternal deaths are related to anaemia.

Sharma $V^{2}$ conducted a cross sectional study in rural area of RS Pora block of district Jammu under the department of community medicine Government Medical College Jammu on 427 females. They found prevalence of anaemia was $90.97 \%$. Of this $32.64 \%$ were mildly anemic, $56.59 \%$ were moderately anemic, and $1.74 \%$ were severely anemic. They concluded that prevalence of nutritional anaemia was high (70.49\%) among the study group.

Iron deficiency is a serious problem in Jammu and Kashmir. Studies have reported that nutritional deficiency is 
particularly a serious problem for young women. $26 \%$ of women in Jammu and Kashmir are undernourished. Overall $59 \%$ of women in $\mathrm{J}$ and $\mathrm{K}$ have some degree of anaemia and $20 \%$ are moderately to severely anemic. ${ }^{3}$

In the clinical area the investigator observed that preexisting anemia is further compromised by multigravidity and insufficient-dietary intake among both rural and urban pregnant women, which has an effect on their health and outcome of pregnancy. Therefore the investigator conducted a study to compare the anemic pregnant women of rural and urban areas of Kashmir and compare their hemoglobin level at 12 weeks, 20 weeks, 28 weeks and 36 weeks based on record analysis in order to elicit prevalence of anaemia in this particular group of women.

\section{Materials and Methods}

A descriptive comparative survey design was used to conduct study in maternity outpatient department of SKIMS district Srinagar on 100 pregnant subjects (50 rural/ 50 urban). Purposive sampling technique was used for sample collection and self structured interview schedule for data collection. An interview schedule was used to collect data regarding demographic characteristics, nutritional status and obstetrical clinical information of study subjects. Assessment Proforma was used for record analysis at 12 weeks, 20 weeks, 28 weeks and 36 weeks of gestation. Data was collected from March 2014 to April 2014. Data collection time was scheduled from 10 to 1PM. Every day 4 to 5 subjects were interviewed individually for 20 to 30 minutes.

\section{Result}

In conclusion the data of the predetermined study revealed the following results.

\section{Section I: Description of Demographic Characteristics}

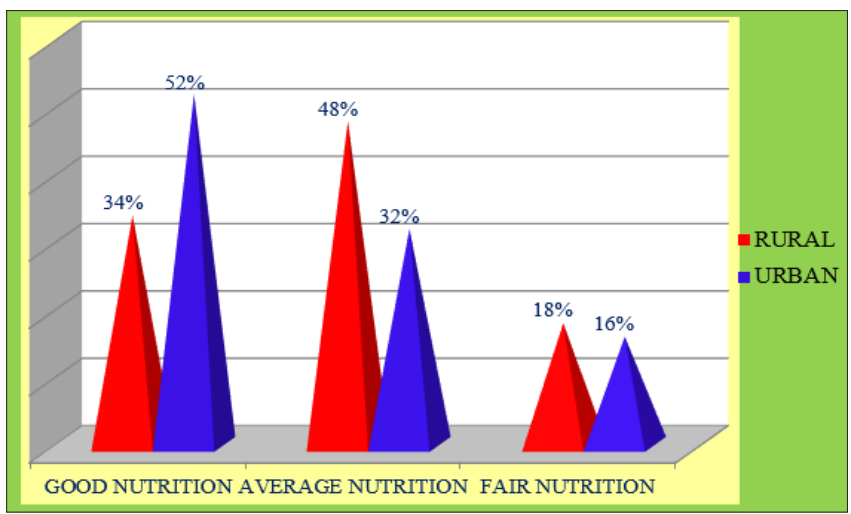

Figure I.Cone diagram showing percentage distribution of rural and urban subjects according to nutritional status
Out of 100 pregnant women majority of rural study subjects $(76 \%)$ were in the age group of 20 to 30 years. Among urban pregnant subjects (50\%) were in the age group of 20 to 30 years and $>30$ years respectively. Among rural pregnant subjects (54\%) were primigravida, 30\% were only multigravida. Among urban pregnant subjects both primigravida and multigravida were only (40\%) in each group respectively. Regarding socioeconomic status (46\%) of rural pregnant subjects belonged to middle income group and $(40 \%)$ belonged to lower income group. Among urban pregnant subjects (52\%) belonged to middle income group and (26\%) belonged to lower income group.

\section{Section 2: Comparative Distribution of Rural and Urban Subjects According to Nutritional Status \\ Comparative Distribution of Rural and Urban Subjects According to Consumption of Iron and Folic Acid and Reason for not taking}

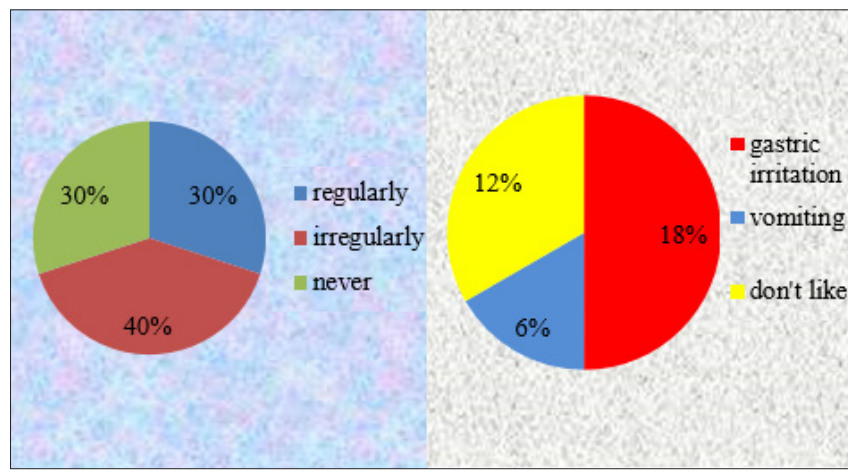

Figure 2.Pie chart showing consumption of iron and folic acid and reason for not taking among rural subjects

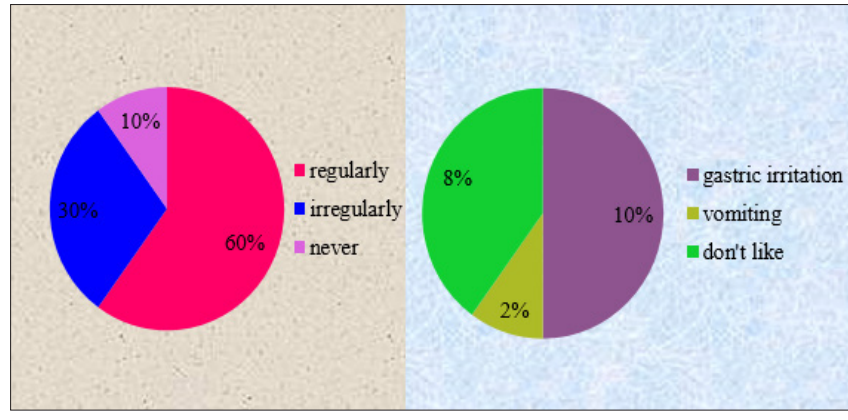

Figure 3.Pie chart showing consumption of iron and folic acid and reason for not taking among urban subjects

Section 3: Comparative Distribution of Subjects According to Obstetrical and Clinical Information

Findings in the Table 1, revealed mild anaemia among 98\% of rural and $100 \%$ of urban pregnant subjects. Moderate anaemia was $2 \%$ only among rural pregnant subjects. 
Table I.Findings of rural and urban pregnant subjects according to physical and physiological measures

\begin{tabular}{|c|c|c|c|c|c|}
\hline \multirow{3}{*}{ Variables } & \multirow[b]{3}{*}{ Sub-items of variables } & \multirow{2}{*}{\multicolumn{2}{|c|}{$\begin{array}{c}\text { n1 = 50 } \\
\text { Rural subjects }\end{array}$}} & \multirow{2}{*}{\multicolumn{2}{|c|}{$\begin{array}{c}\text { n2 }=\mathbf{5 0} \\
\text { Urban subjects }\end{array}$}} \\
\hline & & & & & \\
\hline & & f & $\%$ & $f$ & $\%$ \\
\hline Mild (10-10.9 gms/dl) & Mild anaemia & 49 & $98 \%$ & 50 & $100 \%$ \\
\hline Moderate (7.09.9.9 gm/dl) & Moderate anaemia & 1 & $2 \%$ & 0 & 0 \\
\hline Severe (<7 gem /dl) & Severe anaemia & 0 & 0 & 0 & 0 \\
\hline \multirow{3}{*}{ Urine examination } & Normal urine & 47 & $94 \%$ & 50 & $100 \%$ \\
\hline & Albumin in urine & 0 & $0 \%$ & 0 & 0 \\
\hline & Puss cells in urine & 3 & $6 \%$ & 0 & 0 \\
\hline \multirow{3}{*}{ Oedema } & Puffy face & 10 & $20 \%$ & 8 & $16 \%$ \\
\hline & legs & 0 & 0 & 0 & 0 \\
\hline & feet & 0 & 0 & 0 & 0 \\
\hline \multirow{3}{*}{ Pallor } & Conjunctiva & 6 & $12 \%$ & 4 & $8 \%$ \\
\hline & Dorsum of the tongue & 0 & 0 & 0 & 0 \\
\hline & Nails & 20 & $40 \%$ & 12 & $24 \%$ \\
\hline \multirow{3}{*}{ Status of mother } & General weakness & 15 & $30 \%$ & 10 & $20 \%$ \\
\hline & Fatigue & 10 & $20 \%$ & 8 & $16 \%$ \\
\hline & Shortness of breath on exertion & 11 & $22 \%$ & 8 & $16 \%$ \\
\hline \multirow{3}{*}{ Foetal heart rate } & Normal (120-160 b/mt) & 50 & $100 \%$ & 50 & $100 \%$ \\
\hline & Tachycardia (>1b/mt) & 0 & 0 & 0 & 0 \\
\hline & Bradycardia (<12b/mt) & 0 & 0 & 0 & 0 \\
\hline
\end{tabular}

Section 4: Comparative Distribution of Subjects as per their Grades of Anaemia at Various Weeks of Gestation

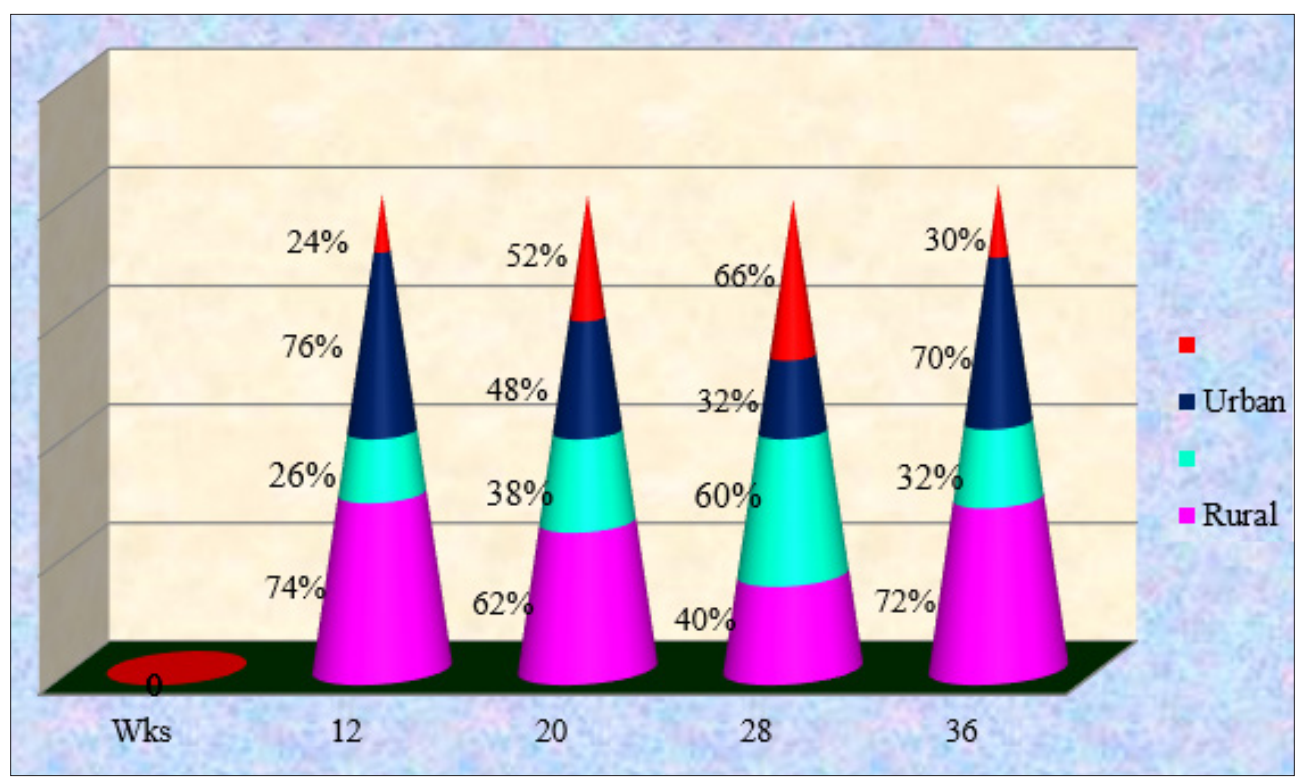

Figure 4.Cone diagram showing percentage distribution of anaemia grades of rural and urban subjects at various weeks of gestation 
Section 5: Association of Nutritional Status of Rural and Urban Subjects with Selected Demographic Variables

Table 2.Findings related to Association of Nutritional Status of Rural and Urban Subjects with Selected Demographic Variables

\begin{tabular}{|c|c|c|c|c|c|c|c|c|c|c|c|}
\hline \multicolumn{4}{|c|}{ Rural subjects } & \multicolumn{2}{|c|}{$\mathrm{n} 1=50$} & \multicolumn{4}{|c|}{ Urban subjects } & \multicolumn{2}{|c|}{$\mathrm{n} 2=50$} \\
\hline \multirow[b]{2}{*}{ Nutritional status } & \multicolumn{3}{|c|}{ Age in Years } & \multirow[b]{2}{*}{ P-value } & \multirow[b]{2}{*}{ Sig. } & \multirow[b]{2}{*}{ Nutritional status } & \multicolumn{3}{|c|}{ Age in Years } & \multirow[b]{2}{*}{ P-value } & \multirow[b]{2}{*}{ Sig. } \\
\hline & $<20$ & $20-30$ & $>30$ & & & & $<20$ & $20-30$ & $>30$ & & \\
\hline Good & 0 & 8 & 1 & 0.494 & NS & Good & 0 & 10 & 9 & 0.494 & NS \\
\hline Average & 1 & 23 & 6 & & & Average & 0 & 10 & 11 & & \\
\hline Fair & 2 & 7 & 2 & & & Fair & 0 & 5 & 5 & & \\
\hline Nutritional status & \multicolumn{3}{|c|}{ Gravida } & & & Nutritional status & \multicolumn{3}{|c|}{ Gravida } & & \\
\hline Good & 6 & 0 & 3 & 0.306 & NS & Good & 10 & 3 & 6 & 0.558 & NS \\
\hline Average & 16 & 4 & 10 & & & Average & 8 & 4 & 9 & & \\
\hline Fair & 5 & 4 & 2 & & & Fair & 2 & 3 & 5 & & \\
\hline
\end{tabular}

NS: Not Significant $(P>0.05)$ at $0.05 \%$ level of significance.

Table 3.Findings related to Association of Nutritional Status of Type of Family with SocioEconomic Status among Rural and Urban Subjects

$[\mathrm{N}(\mathrm{n} 1+\mathrm{n} 2)=100]$

\begin{tabular}{|c|c|c|c|c|c|c|c|c|c|c|}
\hline & & Type o & amily & n $1=$ & & Socio & Economic & tatus & n $2=$ & \\
\hline \multirow{4}{*}{$\begin{array}{c}\text { Rural } \\
\text { subjects }\end{array}$} & $\begin{array}{c}\text { Nutritional } \\
\text { status }\end{array}$ & Nuclear & Joint & P-value & Sig & $\begin{array}{c}\text { High } \\
\text { income }\end{array}$ & $\begin{array}{c}\text { Low } \\
\text { income }\end{array}$ & $\begin{array}{l}\text { Middle } \\
\text { income }\end{array}$ & P-value & Sig \\
\hline & Good & 1 & 8 & \multirow{3}{*}{0.56} & \multirow{3}{*}{ NS } & 4 & 5 & 0 & \multirow{3}{*}{0.012} & \multirow{3}{*}{$S$} \\
\hline & Average & 10 & 20 & & & 3 & 13 & 14 & & \\
\hline & Fair & 3 & 8 & & & 0 & 5 & 6 & & \\
\hline \multirow{3}{*}{$\begin{array}{l}\text { Urban } \\
\text { subjects }\end{array}$} & Good & 8 & 11 & \multirow{3}{*}{0.658} & \multirow{3}{*}{ NS } & 7 & 2 & 10 & \multirow{3}{*}{0.042} & \multirow{3}{*}{$S$} \\
\hline & Average & 7 & 14 & & & 1 & 9 & 11 & & \\
\hline & Fair & 5 & 5 & & & 3 & 2 & 5 & & \\
\hline
\end{tabular}

NS: Not Significant $(P>0.05)$ at $0.05 \%$ level of significance; S: Significant $(P<0.05)$ at $0.05 \%$ level of significance.

Findings in the Table 2, revealed no significant association of nutritional status with selected demographic variables (age in years $P=0.0494$ among both rural and urban pregnant subjects) and gravidity $P=0.306$ among rural and $P=0.558$ among urban Subjects).
Findings in the Table 3, revealed significant association of nutritional status only with socioeconomic status among both rural $(P=0.012)$ and urban $(P=0.042)$ pregnant subjects.

Comparison of Hemoglobin among Rural and Urban Pregnant Subjects at Various Weeks of Gestation

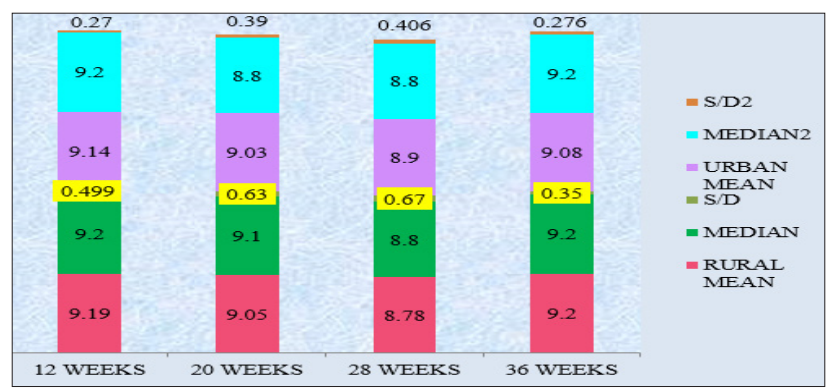

Figure 5.Cyndrical diagram representing comparison of hemoglobin among rural and urban pregnant subjects at various weeks of gestation 
Section 6: Association of Anaemia at 12 Weeks of Gestation among Rural and Urban subjects with Selected Demographic Variables

Table 4.Findings related to association of anaemia at 12 weeks of gestation among rural and urban subjects with selected demographic variables

\begin{tabular}{|c|c|c|c|c|c|c|c|c|c|c|c|}
\hline \multicolumn{12}{|c|}{$[N(n 1+n 2)=100]$} \\
\hline \multicolumn{4}{|c|}{ Rural subjects } & \multicolumn{2}{|c|}{ n $1=50$} & \multicolumn{4}{|c|}{ Urban subjects } & \multicolumn{2}{|c|}{$\mathrm{n} 2=50$} \\
\hline \multirow{2}{*}{$\begin{array}{c}\text { Anaemia at } \\
12 \text { weeks of } \\
\text { gestation }\end{array}$} & \multicolumn{3}{|c|}{ Age in Years } & \multirow{2}{*}{$\begin{array}{c}\text { P- } \\
\text { value }\end{array}$} & \multirow[t]{2}{*}{ Sig. } & \multirow{2}{*}{$\begin{array}{c}\text { Anaemia at } \\
12 \text { weeks of } \\
\text { gestation }\end{array}$} & \multicolumn{3}{|c|}{ Age in Years } & \multirow{2}{*}{$\begin{array}{c}\text { P- } \\
\text { value }\end{array}$} & \multirow[t]{2}{*}{ Sig. } \\
\hline & $<20$ & $20-30$ & $>30$ & & & & $<20$ & $20-30$ & $>30$ & & \\
\hline Mild & 3 & 38 & 8 & 0.240 & NS & Mild & 0 & 25 & 25 & 0.180 & NS \\
\hline Moderate & 0 & 0 & 1 & & & Moderate & 0 & 0 & 0 & & \\
\hline Severe & 0 & 0 & 0 & & & Severe & 0 & 0 & 0 & & \\
\hline \multirow{2}{*}{$\begin{array}{c}\text { Anaemia at } \\
12 \text { weeks of } \\
\text { gestation }\end{array}$} & \multicolumn{3}{|c|}{ Gravida } & & & \multirow{2}{*}{$\begin{array}{c}\text { Anaemia at } \\
12 \text { weeks of } \\
\text { gestation }\end{array}$} & \multicolumn{3}{|c|}{ Gravida } & & \\
\hline & Primi & $\begin{array}{c}\text { 2nd } \\
\text { gravida }\end{array}$ & $\begin{array}{c}\text { Multi } \\
\text { Gravida }\end{array}$ & & & & Primi & $\begin{array}{c}\text { 2nd } \\
\text { gravida }\end{array}$ & $\begin{array}{c}\text { Multi } \\
\text { Gravida }\end{array}$ & & \\
\hline Mild & 27 & 8 & 14 & 0.460 & NS & Mild & 20 & 10 & 20 & 0.30 & NS \\
\hline Moderate & 0 & 0 & 1 & & & Moderate & 0 & 0 & 0 & & \\
\hline \multirow{2}{*}{$\begin{array}{c}\text { Anaemia at } \\
12 \text { weeks of } \\
\text { gestation }\end{array}$} & \multicolumn{3}{|c|}{ Socio- Economic Status } & & & \multirow{2}{*}{$\begin{array}{c}\text { Anaemia at } \\
12 \text { weeks of } \\
\text { gestation }\end{array}$} & \multicolumn{3}{|c|}{ Socio- Economic Status } & & \\
\hline & $\begin{array}{c}\text { High } \\
\text { Income }\end{array}$ & $\begin{array}{l}\text { Middle } \\
\text { Income }\end{array}$ & $\begin{array}{c}\text { Low } \\
\text { Income }\end{array}$ & & & & $\begin{array}{c}\text { High } \\
\text { Income }\end{array}$ & $\begin{array}{l}\text { Middle } \\
\text { Income }\end{array}$ & $\begin{array}{c}\text { Low } \\
\text { Income }\end{array}$ & & \\
\hline Mild & 7 & 22 & 20 & 1.00 & NS & Mild & 11 & 26 & 13 & 1.30 & NS \\
\hline Moderate & 0 & 1 & 0 & & & Moderate & 0 & 0 & 0 & & \\
\hline \multirow{2}{*}{$\begin{array}{c}\text { Anaemia at } \\
12 \text { weeks of } \\
\text { gestation }\end{array}$} & \multicolumn{3}{|c|}{ Type of Family } & & & $\begin{array}{l}\text { Anaemia at } \\
12 \text { weeks of }\end{array}$ & \multicolumn{3}{|c|}{ Type of Family } & & \\
\hline & Nuclear & & int & & & gestation & Nuclear & Jo & int & & \\
\hline Mild & 13 & & 36 & 0.280 & NS & Mild & 20 & & 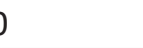 & 0.340 & NS \\
\hline Moderate & 1 & & 0 & & & Moderate & 30 & & 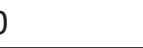 & & \\
\hline
\end{tabular}

NS: Not significant $(P>0.05)$ at $0.05 \%$ level of significance.

Findings in the Table 4 did not reveal any significant association of anaemia at 12 weeks of gestation with any of the demographic variables.
Findings in the Table 5 did not reveal any significant association of anaemia at 12 weeks of gestation with nutritional status among both rural and urban pregnant subjects.

Table 5.Findings related to association of anaemia at 12 weeks of gestation among rural and urban subjects with nutritional status

$[\mathrm{N}(\mathrm{n} 1+\mathrm{n} 2)=100]$

\begin{tabular}{|c|c|c|c|c|c|c|c|c|c|}
\hline \multicolumn{3}{|c|}{ Rural } & \multicolumn{2}{|c|}{$\mathrm{n} 1=50$} & \multicolumn{3}{|c|}{ Urban } & \multicolumn{2}{|c|}{$\mathrm{n} 2=50$} \\
\hline $\begin{array}{c}\text { Nutritional } \\
\text { status }\end{array}$ & $\begin{array}{c}\text { Mild } \\
\text { anaemia }\end{array}$ & $\begin{array}{c}\text { Moderate } \\
\text { anaemia }\end{array}$ & P-value & Sig. & $\begin{array}{c}\text { Nutritional } \\
\text { status }\end{array}$ & $\begin{array}{c}\text { Mild } \\
\text { anaemia }\end{array}$ & $\begin{array}{c}\text { Moderate } \\
\text { anaemia }\end{array}$ & P-value & Sig. \\
\hline Good & 9 & 0 & \multirow{3}{*}{1.126} & \multirow{3}{*}{ NS } & Good & 19 & 0 & \multirow{3}{*}{1.198} & \multirow{3}{*}{ NS } \\
\hline Average & 29 & 1 & & & Average & 21 & 0 & & \\
\hline Fair & 11 & 0 & & & Fair & 10 & 0 & & \\
\hline
\end{tabular}

NS: Not significant $(P>0.05)$ at $0.05 \%$ level of significance. 


\section{Discussion}

The study found Prevalence of anaemia among both rural and urban pregnant subjects. Results showed that prevalence of anaemia had no relation with age, parity and type of family. These findings were supported by Bhargavi et al. ${ }^{4}$, and Judit $A^{5}$ who found prevalence of anaemia among rural and urban pregnant subjects without any relation of anaemia with age, parity, and type of family among the study subjects. Regarding socioeconomic status the study found mild anaemia among all the study subjects belonging to high income group, middle income group and fair income group. Similar findings were supported by the study done by Ibrahim et al. ${ }^{6}$ and Haldar ${ }^{7}$ in their study they have reported prevalence of anaemia among pregnant subjects belonging to same income groups respectively. Regarding consumption of iron supplements $40 \%$ of rural and $30 \%$ of urban pregnant subjects reported irregular consumption of iron supplements and regular consumption of supplements was reported by majority of urban subjects only. The reason for not taking supplements included gastric irritation (18\%), (10\%) among both rural and urban subjects respectively. These findings are supported by the study done by Chandra8who found that $59.68 \%$ took IFA tablets and $40.32 \%$ did not take. Among 74 subjects who received IFA tablets, only (70.27\%) pregnant women took the tablets regularly and remaining $29.73 \%$ took the tablets irregularly. The study found that $98 \%$ of rural subjects had mild anaemia and $2 \%$ had moderate anaemia. Among Urban, $100 \%$ of pregnant subjects had mild anaemia only. These findings are supported by Barbin et al. ${ }^{9}$ who found $10.4 \%$ of pregnant subjects had mild anaemia, $4.2 \%$ had moderate anaemia and $0.3 \%$ had severe anaemia. Regarding anaemia at various weeks of gestation the study found $74 \%$ of rural subjects had mild anaemia at 12 weeks, $62 \%$ at 20 weeks and $72 \%$ at 36 weeks Among urban subjects $76 \%$ had mild anaemia at 12 weeks and $70 \%$ had at 36 weeks of gestation respectively. Moderate anaemia was found in $60 \%$ of rural subjects and $66 \%$ of urban subjects at 28 weeks of gestation respectively. Severe anaemia was not observed in any pregnant subject. These findings are supported by the study done by Mafiana et al. ${ }^{10}$ who found $44.6 \%$ prevalence of anaemia among those subjects who registered in the 1 st trimester, $64.4 \%$ in the 2 nd trimester and $64.6 \%$ in the $3 r d$ trimester $P=<0.05$.The study did not find any significant association of nutritional status with age and gravidity among both rural and urban pregnant subjects These findings are supported by the study done by Madhavi et al., ${ }^{11}$ they have reported that prevalence of anaemia was not statistically significant with relation to age of women $\mathrm{P}>0.05$, and parity also did not show any significant relation with anaemia Similarly association of nutritional status with type of family among both rural and pregnant urban subjects was not found significant $P$
$=0.56 / \mathrm{P}=>0.658$. These findings are further supported by Judith et al. ${ }^{12}$ who found that there was no significant association of nutritional status with type of family both among rural and urban pregnant subjects. But association of nutritional status with socioeconomic status among both rural and urban pregnant subjects was found significant $P$ $=0.012 / \mathrm{P}=0.042$. These findings are supported by the study done by Mehta et al. ${ }^{13}$ who also found significant association of nutritional status with socioeconomic status among both rural and urban pregnant subjects. Regarding association of Haemoglobin the study did not find any significant association of anaemia at 12 weeks of gestation with all the selected variables among rural and urban study subjects. These findings are supported by Mehta ${ }^{13}$ who also did not find any significant association of anaemia with age, parity, type of family and socioeconomic status among both rural and urban pregnant subjects. Regarding association of anaemia at 12 weeks of gestation the study did not find any significant association of mild and moderate anaemia with nutritional status among both rural and urban pregnant subjects. These findings are supported by Ibrahim SA et al6.who also did not find any significant association of mild and moderate anaemia with nutritional status among both rural and urban pregnant subjects.

\section{Conclusion}

The burden of anaemia during pregnancy posses a great threat to the life of both mother and baby. The findings of the present study revealed highest association of nutritional status with socioeconomic status among both rural and urban pregnant subjects. It is found that supplementation alone does not overcome the burden of anaemia among this vulnerable group but it should be supported with verbal information, discussion, and written information about easily available and affordable foods. It also indicates that due to shortage of nursing staff in overcrowded ante- natal clinics concerns this high risk group cannot be addressed which may be probably due to posting of one staff in antenatal clinics that remains busy in giving immunization and iron infusion.

\section{Conflict of Interest: None}

\section{References}

1. Kiran B. Iron deficiency anaemia. Women's Era 2005; 1: 149-50.

2. Sharma V. Nutritional anaemia among currently married females in the reproductive age group rural Jammu. Journal of Evolution of Medical and Dental Sciences 2013; 12(42): 8176-85.

3. Rahi. Anaemia in JK women. 2014.

4. Vemulapalli B. Prevalence of anaemia among pregnant women of rural community Vizianagaram North coastal Andhra Pradesh. Asian Journal of Medical Sciences 
2014; 5: 4-25.

5. Judit A. prevalence of anaemia among pregnant women. A community based study in udupi district Karnataka. Health and Population-Perspectives and Issues 2008; 31(1): 31-40.

6. Ibrahim SA. Socio-demographic and maternal factors in anaemia in pregnancy at booking in Kano, North Nigeria. African Journal of Reproductive Health 2011; 15 (4): 33-41.

7. Haldar. Correlates of anaemia among pregnant women in rural area of West Bengal. Journal of Family Welfare 2013; 24(4): 50-5.

8. Chandra CP. Knowledge and attitude of community towards rich sources of vitamin A and Iron in relation to malnutrition. North Gondar, Ethiopia. The Ethiopian Journal of Health Development 2004; 14 (1): 23-9.

9. Gies S. Comparison of screening methods for anaemia in pregnant women in Awassa Ethiopia. European Journal of Tropical Medicine and International Health 2003; 8(4): 301-9.

10. Idowu OA, Mafiana CF, Dapo S. Anaemia in pregnancy. A survey of pregnant women in Abeokuta Nigeria. African Health Sciences 2005; 5(4): 295-9.

11. Madhavi LH. Nutritional status of rural pregnant women. People's Journal of Scientific Research 2011; 4(2): 20-3.

12. Samuel T. Maternal micronutrient deficiencies in early pregnancy and infant nutritional status in Urban South India. Maternal Child Nutrition, 2013.

13. Mehta et al. Maternal micronutrient deficiency in early pregnancy and infant nutritional status in urban South.Indian.Maternal Child Nutrition Jan 2013;Tampubutafib/bitstream/handle/10024/68151. 